\title{
Organized Crime in Europe
}

\section{KOSLOWSKI, Ricco ${ }^{1}$}

\begin{abstract}
The study introduces the current situation in connection with organized criminal groups in Europe. By differentiation of their specific characteristics, the activity of terrorist and organized crime groups in Europe are presented. The author provides some insight into the activity of the currently working organized crime groups through the assessment of the activity of transnational organized crime groups. In the forecast of future evolution of organized crime, the author emphasizes the importance of regular cooperation at national and international, as well as inside and outside of the competent organizations.
\end{abstract}

Keywords: transnational organized crime, Europe, cooperation

\section{Organized Crime}

\section{Definition}

The official definition of Organized Crime in Germany (1990/RiStBV 1991) states:

Organized Crime (abbreviated to $\mathrm{OC}$ ) is the deliberate commission of criminal offenses, determined either by profit or power, which is of considerable importance individually or in its entirety, if more than two parties interact for a longer or indefinite time using commercial or businesslike structures applying violence or other means of intimidation, or under influence on politics, media, public administration, justice, or economy.

\section{Forms of Appearance}

Organized crime usually occurs in hierarchically organized forms of organizations; but there are also network-like, functionally differentiated forms of organizations. Irrespective of this, criminal organizations are often supported by ethnic solidarity, language, customs, as well as social and family background. Thus, arose among the individual members a system of personal and business criminally usable connections, in which there are often very strong relations of authority and dependency and sanction possibilities for dissenters.

KOSLOWSKI, Ricco, PhD, Goethe Universität, Frankfurt

https://orcid.org/0000-0002-0251-6727, koslowski@apokas-international.de 


\section{Indications of Organized Crime}

Because of the planned, long-term oriented approach and the business-like structures (systematic prey utilization, work to order, precise planning, investigation of market needs), it is not surprising that the perpetrators of organized crime are mostly professional. In order to keep the structure of the group secret and to avoid identifications, straw men are often used.

Another hallmark of organized crime is the help provided to group members by the organization. For example, expensive lawyers and high security contributions are paid, escape aid provided, others involved in legal proceedings intimidated and witnesses provided.

Conspiratorial elements such as the use of aliases or codes and the simultaneous use of multiple mobile phone cards are also a common part of organized crime. In contrast to the outside world, organized criminal groups often isolate themselves, which is expressed in internal conflict resolution mechanisms, in which the police are not involved, and a lack of willingness to express them. In order to avoid prosecution and other problems, corruption is often used and dependencies created (for example through sex, gambling or usury), which allow blackmail.

If organized crime groups appear to the public, they are anxious to convey a certain image of themselves. Their public relations are therefore usually controlled.

\section{Demarcation to Terrorism}

In contrast to terrorism, in which crimes are committed to achieve political goals, the crimes committed in organized crime are characterized by the (material) profit motive of the perpetrators. Non-profit crime (for example politically or religiously motivated) does not fall under the definition of organized crime. The German Criminal Code therefore, distinguishes between Organized Crime ( $\$ 129$, Formation of a Criminal Association) and Terrorism ( $\$ 129$ a, Formation of a Terrorist Association).

In reality, however, the distinction between these different forms is difficult, as terrorist groups increasingly use organized crime to finance themselves or make contacts with criminal networks, which, for example, are helpful for the purchase of weapons. At the same time, it may be beneficial for organized crime to make contact with terrorist groups, as in most states most of the crimes committed by the latter are punished differently from "ordinary crime".

\section{Transnational Organized Crime}

According to the United Nations, organized crime is cross-national (transnational) if at least one of the following criteria is met: Organized crime is exercised in more than one state. Committed in one state, but much of its preparation, planning, direction or control happens in another state. Committed in one state, but it involves an or- 
ganized criminal group operating in more than one state. Committed in one state but has a strong impact on another state. Important organized criminal activities such as smuggling or trafficking are transnational.

\section{Fields of Activity}

Organized crime uses all fields of activity with high profit margins. Particularly relevant are human trafficking (there is now a higher turnover than in drug trafficking), drug trafficking, fraud, credit card fraud, smuggling, protection racketeering, white collar crime, illegal arms trade, counterfeit money, abduction, money laundering, nuclear crime, girls or children trafficking for the purpose of sexual exploitation or using them as workers, piracy, evasion of embargoes, environmental crime, gambling, nightlife, car theft or car shedding, art and antiquities theft.

\section{Effects}

Organized crime has a destabilizing effect on domestic security, state order and the functioning of the economic system. Since the effort to combat them is high, it can lead to the emergence of parallel societies and the emergence of law-free areas. The strong presence of organized crime in a society can lead to the fact that the law of the respective state is obviously not sufficiently applied so that the legal order is no longer accepted.

\section{Profit Recovery}

Most of the profits made by organized criminal activities are returned to the legal economy through money laundering. This can happen via own or foreign legal enterprises, letterbox companies or bank accounts (often in so-called tax havens).

\section{Organized Crime in Europe}

In recent years, Germany has increasingly changed from a retreat to a business area of organized criminal groups, but direct use of force has played only a minor role in international comparison. The focus of their activities is in cities and metropolitan areas.

Organized crime in Germany is not characterized by a single structural model; rather it is characterized by dominant individuals or groups. In purely domestic organized crime, net-like structures are more likely to be found as a tight organization; occasionally there are also hierarchical structures ("cells"). Increasingly, however, Mafia-style criminal organizations characterized by ethnic cohesion are gaining in importance. Examples are:

- Russian blackmailers of protection money/arms dealers

- Romanian burglars/pickpockets 
- Shell game players/arms dealers from former Yugoslavia

- Polish car thieves/car shifters

- Vietnamese cigarette dealers

The behaviour of the perpetrators is oriented specifically to the government control strategies; thus, business is carried out with varying degrees of involvement, and legal and illegal business is interwoven. It is noticeable that the individual persons involved are less isolated than the respective individual transactions are separated from each other. Thus, without agreement, increasingly distinct "business areas" emerge.

\section{The Appearance of Organized Crime}

\section{General}

There is no uniform structural model for all local and sector-specific areas of the organized crime. In the Federal Republic of Germany essentially two basic forms must be assumed:

Interconnections of offenders, which are concentrated in the conurbations, and

Independent groups with a more or less firm staff structure, which partly work from abroad into the Federal Republic of Germany.

The emphasis is clearly on the interconnections of offenders. In German crime circles applies:

Why should one bind themselves, if the system works great in other looser ways? Even foreign offenders living in the Federal Republic today largely adapted their actions to this maxim.

In case of independent groups, predominantly foreign perpetrators profit most from the German market.

Both systems are essentially trading under the same business conditions.

In the overall picture, the Federal Republic of Germany is to be regarded as an operational area in which all regions are more or less developed through personal and business connections useable in criminal ways. At the same time, major focal points have formed in the major cities of metropolitan areas. The connections very often extend to foreign countries.

Single dominating individuals/groups are emerging from the organized crime perpetrator circles, mainly because of their special financial resources and their connections. The leadership style is consistently described as relaxed. Only in some individual foreign groups, an authoritarian style of leadership is practiced.

Absolute leaders in the sense of "godparents" like in the mafia do not exist in the Federal Republic. Rather, the principle of "money is power" is particularly true in the German organized crime scene. Well-funded customers and financiers are recognized with certainty as dominating persons or persons in charge. They are the source and engine of the organized crime and must, therefore, be of special interest for the police. 
The "cohesion in the organization" is based mainly on the common interests and the common benefits. The prospects of leadership, the secure workplace with the secure merit in the circle of the contractors and helpers and the common front against the police have made the organized crime-crime circles to a community of solidarity mature. In foreign groups, however, a sense of belonging to a group is more pronounced due to regional team and family ties. Overall, ideational or ideological motives for cohesion are rare to find. Basically, self-interest is in the foreground. Every single actor prefers independence and joins partners only if the circumstances make this absolutely necessary or if he can benefit more from this. This behaviour has a significant impact on the persistence of associations of perpetrators.

Thus, in general, a strong fluctuation in the interaction between individual actors and in the composition of temporary special purpose communities can be assumed. If special offense know-how or special logistics are required for the offense inspection, a certain degree of permanence may gradually emerge.

The fluctuation does not relate to the perpetrator contacts. Consistent and proven "connections" form the actual business foundation. The quality of the usable compounds determines the amount and resilience of the achievable profits.

Reprisals against helpers or contractors are usually not required to ensure cohesion in the scene. The use of force against persons in organized crime offender circles does not have the value that was previously intended, although from time to time physical impacts - especially in foreign groups with an authoritarian style of leadership - quite occur.

The assessment of individual officials or departments, which are repeatedly confronted with individual authoritarian and violent (usually foreign) leaders due to jurisdictional rules or specific local circumstances, can however deviate from the overall picture. However, considering the multitude of actors, their different characters and their exaggerated profit motive, the interviewed experts no longer rate (even spectacular) cases of violence against persons as symptomatic of the organized crime of the 1980s, which generally acted rather quietly.

\section{Conclusion}

One cannot look for violence if one wants to find organized crime. This principle will become increasingly important in the future.

On the other hand, it is not uncommon to practice pressure of all kinds, especially against business competitors, from price pressure to threat. Violent actions against property cannot be ruled out. Although no typical organized crime features can be found here, cases of property damage combined with other facts often serve the police as a starting point for targeted investigations against organized crime offender groups.

For the last few years, it has become clear that they increasingly arrange or allow themselves to be granted. Disputes lead to unrest in the scene, which in view of the increased vulnerability to police attacks cannot be in the interest of the relevant persons. 
Moreover, one increasingly moves in ("business") circles where violence is not common practice. The decline of violent conflicts noted by many test persons in recent years points to a growing agreement and a progressive organization of the perpetrators.

It can be assumed that the course of a major illegal business is not in the hands or duties of just one group of perpetrators, but that criminal organizations, temporary special purpose associations and individual actors cover individual "business segments" in a constant or changing role play. This can be done either in the form of purposeful assignment of tasks and division of labour, or - which is not uncommon - the demarcated business area arises without consultation when the perpetrator or the circle of perpetrators discover a gap and fill it independently.

\section{Knowledge by the German BKA and other International Law Enforcement Agencies}

\section{Bundeskriminalamt (BKA - Federal Criminal Police Office)}

The role of the BKA is to serve as the Federal investigative police agency of Germany. The origination of the BKA is based on the German Constitution, allowing the federal government the authority to pass laws on the organization of criminal policing in Germany. The Bundeskriminalamt (BKA) and the "Law on the Establishment of a Federal Criminal Police Office" were both established in 1951. The "Criminal Police Office for the British Zone" or Federal Criminal Police Office in Hamburg became the BKA shortly afterward. Within the same year, Wiesbaden was declared the headquarters for the new criminal police agency.

Advancement in technology and both political and social changes are major factors that have affected the direction and evolution of the BKA as the criminal police of the Federation. The development and role of the BKA within both the security structure in Germany and internationally are closely associated with the national and international crime progression and development. In order to maintain consistent performance of duties, the BKA has continued to evolve and adjust its internal structure and working methods in response to the changing forms and methods crimes are committed and the shifting geographical locations.

Events in the last 50 years are reflected in the organizational and development of the BKA. Initially, the BKA operated as the national central police agency, providing international co-operation. Throughout the 1970s-1980s, the Red Army Faction terrorist campaign impacted the work of the BKA. During the mid-1980s, the BKA focused primarily on handling the expansion of international narcotics trafficking and rise in organized crime in parallel with combatting terrorism. This was followed in the 1990s by the unification of East and West Germany to form present-day Germany and formation of the EU. In the $21^{\text {st }}$ century, the coordinated terrorist attack on the United States by al-Qaeda on September 11 brought international terrorism to the forefront of security policy worldwide, forcing agencies to review their internal structure and 
communication with other agencies. Additionally, the BKA is faced with new challenges attributed to the accelerated advancement in the areas of information and communications technology (ICT) utilized by criminals for their illicit activities.

In response to the changing criminal landscape, the "Joint Counter-Terrorism Centre" (GTAZ) was established in Berlin in 2004. The GTAZ serves as a central station for collecting intelligence on international terrorism and distributing it to the German law enforcement, intelligence and other public agencies with the focus on optimizing communication and working on a collaborative level. Rather than an independent agency, the GTAZ is considered a communication platform and centre for involved agencies to work cooperatively. The creation of the "International Coordination" division in January 2005 followed, further improving the communication and co-operation with international counterparts and strengthening the ability to counter international terrorism.

The present structure of the BKA is based on the last reorganization that took place in 2016. The BKA is currently comprised of over 5,000 employees from various professional groups, including members of law enforcement, forensic and natural scientists, public servants, and researchers specializing in law enforcement and criminology. Together the groups create a dedicated and sophisticated coalition to ensure the BKA's high reputation as an effective partner in the worldwide fight against crime.

\section{Transnational Organized Crime/Crime Threats in General}

Transnational organized crime (TOC) is defined as "organized crime coordinated across national borders, involving groups or networks of individuals working in more than one country to plan and execute illegal business ventures against the fundamental values of the international community". The crimes may be committed in one country but the criminal activities involve cross-border transference and have an impact on another country. The structural organization of the TOC groups are typically networks, pyramidal, clans, or cells, with some progressing into other forms; however, typically operating as isolated groups. The common characteristic of the TOC groups is the goal to gain power, influence, and financial gains through violence, corruption, exploitation of national boundaries and use of sophisticated communication methods.

TOC crimes are aimed at financial profit or to gain an economic advantage and involve narcotics trafficking, money laundering, human smuggling, human and weapons trafficking, illegal gambling, extortion, counterfeiting, endangered species smuggling, cultural artefacts smuggling and cybercrime. Economies are compromised and disrupted due to the immense amount of money involved. Governments are also negatively impacted and may be undermined through the corruption of government officials.

TOC groups are geographically and ethnically diverse with connections to countries in the Middle East, Asia, Africa and throughout Europe. The advances and widespread availability of international communication and the internet provide TOC groups the opportunity to utilize cyber techniques to target and expand criminal activity outside of their geographical location resulting in a global impact. Examples of transnational 
cyber-crimes committed by TOC group include obtaining information through phishing, manipulation of the stock market, establishment of illegal gambling operations, money laundering and advanced fee fraud schemes. Off shore servers allow TOC groups to expand criminal activity with anonymity. The increase and expansion of transnational organized crime has been a negative consequence of globalization. Geographical location no longer serves as a restrictive factor or reflection of the possible threat for the spread of criminal activity.

The global risk to public welfare from human trafficking and counterfeit or stolen pharmaceuticals, undermining democratic governments through corruption of government officials, and destabilization of economies from the monetary impact resulting from the crimes are all significant security concerns on a national and international level.

\section{Balkan Groups}

The Balkan TOC groups are associated with Romania, Albania, Bosnia-Herzegovina, Bulgaria, Croatia, Montenegro, Kosovo, Serbia, the former Yugoslav Republic of Macedonia, and Greece. These groups tend to follow a traditional clan structure with ethnic, friendship and familial connections.

In approximately the $15^{\text {th }}$ century, the kanun, or "code", served as the structural operational basis for the clans that formed in rural countries. The kanun instituted a structure based on similar values, secrecy and loyalty. Territories were controlled by the regional clan which often led to violent outbreaks between clans in order to protect activities. This operational structure provided the basis for what is today the Balkan organized crime groups.

The Balkans were originally under Communist rule, providing an environment facilitating black market activity but restricting expansion outside of the geographical location. The fall of Communism and economic upheaval in the late 1980s to early 1990s, resulted in the international expansion of the Balkan organized groups and new criminal enterprises and profit generating schemes.

Characteristics of the Balkan TOC groups are flexibility and project-based crimes. The groups tend to be technologically skilful, using cyber tools to commit fraud and further expand criminal activity. Other criminal activities involve drug trafficking, human smuggling, human trafficking, identity theft, counterfeit documents, real-estate fraud, health and insurance fraud, and extortion.

\section{Italian Organized Crime/Mafia}

The Mafia, or Italian criminal enterprise, first appeared in the 1800s in Italy and eventually spread internationally with a worldwide network. The word Mafia originally referred to "a man of honour", a "manly" person with principles based on protection of family and friends, operating under a code of silence until death. 
The Mafia started as a secret society of resistance fighters and was organized to fight invaders and domination in a vigilante-style justice following a 3,000-year period of invasion and exploitation by numerous dominating armies. Over time, Sicilians adapted a secret society of vigilante-style resistance fighters organized to fight invaders. The clan-type structure based on familial ties served to protect and provide justice. Profits incurred by their actions were considered at the cost of the oppressor and, therefore, of minimal concern. Gradually, the groups once consisting of honourable men evolved into the notorious Sicilian Mafia criminal organization that emerged in the 1920s.

The Mafia has one of the most internationally connected and recognized criminal organizations with operation and associations with other criminal groups in North and South America, Australia, and sections of Europe. The largest and most powerful "families" are La Cosa Nostra (LCN), the Sicilian Mafia, The 'Ndrangheta (Calabrian Mafia), the Camorra and Sacra Corona (The United Sacred Crown). These groups have an estimated 25,000 members and a quarter million associates.

\section{La Cosa Nostra}

La Cosa Nostra (LCN) translated as "this thing of ours", is one of the leading organized criminal threats to American society. It encompasses a loose association of different criminal groups "families" with a shared code of conduct and organizational structure. Each "family" has claims over a specific territory such as a town, village, or neighbourhood in which they operate their illegal activities or rackets. Criminal activities include extortion, murder, corruption of government and state officials, drugs and human trafficking, tax-fraud, stock manipulation, gambling, infiltration of legal businesses, loan sharking, and pornography. The "families" form a nationwide alliance based on family relationships and protection with the shared pursuit of criminal activities.

Presently, LCN is based in Italy and cooperates with various criminal syndicates in ongoing criminal activities.

\section{Sicilian Mafia}

The Sicilian Mafia, based in Sicily, became an international organized crime group in the 1900s and is now estimated by some experts as the second largest organization in Italy. Heroin trafficking, military weapons trafficking and government corruption are all specialties of this group. Other activities are common to other organized crime groups such as racketeering, fraud, arson and counterfeiting.

The Sicilian Mafia is notorious for its aggressive attacks on both government, judicial and high-ranking law enforcement victims. High profile murders are referred to as an "excellent cadaver" to differentiate an assassination of a prominent official by the Mafia from the murder of an ordinary citizen or criminal.

\section{'Ndrangheta (Calabrian Mafia)}

In the 1860 s a group of Sicilians was exiled by the Italian government to Calabria. There they formed small criminal groups referred to as the "Ndrangheta" which means 
courage or loyalty in Greek. In the late 1990s and early 2000s, the 'Ndrangheta became the most powerful criminal organization in Italy. According to Europol in 2013, "the 'Ndrangheta is among the richest and most powerful organized crime groups at a global level."

An approximate 6,000 members related by marriage or family make up about 160 "Ndrangheta" cells. Originally involved in extortion and blackmailing, the groups have expanded their present-day criminal scope into money laundering, counterfeiting, fraud, loan sharking, alien smuggling, narcotics trafficking, murder, gambling, bombings, theft, and labour racketeering, and specializing in political corruption and kidnapping.

\section{Camorra (Neapolitan Mafia)}

The Camorra roots can be traced back to groups of released prisoners in Naples, Italy in the 1800s. The word "Camorra" translates to "gang". The groups formed clans in the cities and continued to grow in number and power. It is the largest organized Italian crime group with an estimated 111 clans composed of 7,000 members extending from Naples and into the surrounding areas. Unlike the pyramidal structure of the Sicilian Mafia with a centralized organization, the Camorra is organized horizontally with each Camorra clan acting independently.

A major period of financial leverage for the Camorra group was following the 1980s earthquake in the Campania area of Italy. Reconstruction was largely carried out by operations controlled by the Camorra. The group continues to control cigarette smuggling and collect payoffs from other criminal groups involved in cigarette trafficking. Other crimes committed include blackmail, political corruption, counterfeiting, money laundering, extortion, human smuggling, robbery and kidnapping.

Sacra Corona Unita

Similar to the Camorra group, the Sacra Corona Unita founders were released prisoners that settled in the Puglia area of Italy. They continued to grow and become a recognized power in the 1980s. In total, there the Sacra Corona Unita is comprised of approximately 2,000 members amongst 50 clans.

The organization specializes in smuggling of humans, drugs, and cigarettes; however, it is also involved in extortion, government corruption and money laundering. Other criminal groups utilizing the southeast coast of Italy to smuggle goods to and from eastern European countries provide payoffs to the organization for docking rights.

\section{Middle Eastern Groups}

TOC groups from the MENA (the Middle East and North Africa) countries include Afghanistan, Egypt, India, Iran, Iraq, Israel, Jordan, Lebanon, Morocco, Oman, Pakistan, Syria, the United Arab Emirates and Yemen. They are connected by tribal or familial ties with crime centred around financial fraud or organized theft. Small storefronts typically serve as the basis for the criminal operations. Ethnic lines are often crossed 
to cooperate in mutually profitable criminal activities. The operations can be highly sophisticated and depend on an extensive international network of criminal partnerships.

Middle Eastern transnational criminal organizations are associated with various forms of fraud including financial, document, health care and identity fraud. Additional illegal activity ranges from traditional crimes (money laundering, auto theft, smuggling of stolen property and cigarettes and narcotics trafficking) to trademark counterfeiting and cargo theft of infant formula for redistribution.

\section{Asian Groups}

The two subgroups of Asian criminal enterprises, traditional and non-traditional. The traditional criminal enterprises are the Chinese triads and the Japanese Yakuza or Boryokudan with roots in the countries of ethnic origin. The Chinese triads are a notorious TOC group emerging from Chinese monks formed to fight injustice in the $18^{\text {th }}$ century and evolving into the criminal crime operations found today and based in the major cities of Hong Kong, Macau and Taiwan. The Yakuza have origins tracing to the Japanese Edo period in the 1600s and started as groups of peddlers and gamblers.

Non-traditional criminal enterprises are TOC groups formed in countries with large neighbourhoods of Asian communities. Recognized groups, various Asian street gangs such as the Chinese Tongs and triad affiliates with loose ties to their respective ethnic country of origin; however, operating as independent entities. The Chinese Tongs, was initially a social group that evolved into a criminal organization and a century later has joint organizations with connections to East and Southeast Asia including China, Korea, Japan, the Philippines, Vietnam, Laos and Thailand. Groups emerging from the South Pacific island regions are now becoming notable and visible threats. Economic globalization, communications technology, accessibility to international travel and lax immigration policies have allowed for the growth and influx of the Asian criminal enterprises and ability to immigrate undetected.

Characteristics of these Asian criminal enterprises are intermixing of legitimate businesses such as small storefronts to corporate level companies with illegal activities, allowing some enterprises to commercialize criminal activities. Additional characteristics are flexibility and mobility of the complex networks of national and international criminal associates, extensive financial resources, adaptability to the environment, multi-lingual ability and sophisticated operations involving overseas counterparts. The groups are known to cooperate with other groups, crossing racial and ethnic lines and combining resources when necessary to conduct complex schemes.

Asian criminal enterprises are involved in traditional organized crime such as illegal gambling, prostitution, loan sharking, murder and extortion, and have expanded to international level crimes - money laundering, alien smuggling, drug trafficking (mainly heroin and methamphetamine), financial fraud, auto theft, counterfeiting and piracy 
of intellectual property. Also notable is the expansion into white collar crimes by intermixing legitimate business ventures with illegal activities.

\section{Eurasian Groups}

Eurasian TOC are not only groups originated and operating in Russia but includes countries formerly part of the Eastern bloc. The groups are involved in a multitude of criminal activities and align themselves with other criminal organizations. Illicit activities range from fraud in the healthcare and securities/investment industries, worldwide money laundering, car theft rings, assassination, extortion, narcotics trafficking and interstate transportation of stolen property.

The dissolution of the Soviet Union in 1991 caused an economic upheaval throughout Russia and the former Soviet bloc countries. The environment provided an opportunity for corrupt public officials and competing business men aligning with criminals to gain control of resources and privatize industries in the new free market "free-forall". Boris Yeltsin, the first elected president of the Federation of Russian States, stated in February 1997 that, "Organized crime has become the No. 1 threat to Russia's strategic interests and to national security. [...] Corrupted structures on the highest level have no interest in reform".

In the Western world, crime groups emerged following the Soviet Refuseniks' emigration to Europe, Israel and the United States in the 1970s. After the collapse of the Soviet Union, the Refusenik criminals assisted other criminal organizations to expand to the West. These groups are responsible for undermining the government of the former Soviet Union through embezzlement, plundering of national resources, corruption of government officials and tax evasion. The possible destabilization of the government and economy of the former Soviet Union by criminal activities are threats of paramount importance to political and national security. An overarching national security concern is the involvement in nuclear weapons trade in the black-market.

\section{African Crime Groups}

Since the 1980s, the economic world globalization and advances in communications technology has attributed to the rapid development of the African TOC. International banking, travel and trade have provided opened what was once local and regional crimes into networks capable of targeting international victims in wealthy and developed countries. Weak governance, internal conflict and unstable economic conditions found in African countries such as Nigeria, Liberia and Ghana provide an environment for some of these activities to flourish and expand.

The most prominent and lucrative illicit activity for the Nigerian groups is drug trafficking. Specifically, cocaine from South America into Europe and South Africa and heroin from Southeast and Southwest Asia into Europe and the United States. Methamphetamine manufacturing and distribution is an emerging concern in the drug 
economy of Africa. A key period in the growth of African TOC involvement in international drug trafficking occurred in the late 1990s to early 2000 which coincided with increased law enforcement in the cocaine transit hub in the Caribbean region, shifting the supply transit route to West Africa. The related money laundering from drug trafficking has transformed the Nigerian groups into a major international criminal presence.

Global financial fraud has also become synonymous with Nigerian groups. Fraud schemes include auto insurance, healthcare billing, life insurance, credit card, bank, check, 4-1-9 letters or advance-fee fraud and document fraud used to create false identification. Victims are targeted on all levels and include individuals, businesses and government offices. The widespread internet and e-mail accessibility have dramatically increased the landscape for profit potential and frequency. Other criminal markets include human smuggling from Africa to Europe, trafficking of counterfeit pharmaceuticals and firearms, as well as traditional crimes.

\section{Western Hemisphere}

Worldwide source and production of coca come from "source zone" countries, specifically Colombia, Peru and Bolivia. Drug manufacturing and trafficking remain the major crime identified with source zone countries; however, other related offenses affecting national and international security are money laundering, weapons trade, alien smuggling and human trafficking. Much of the violence witnessed in the source zone is accredited to the transnational criminal organizations that are supported and strengthened by the illicit activities.

Transit zone countries are nations that geographically separate drug producing countries from the main consumers. Mexico and Central American countries (specifically El Salvador, Nicaragua and Panama) are identified as important transit zone countries. In the last decade, the drug flow through Central America has drastically increased and coincides with the increased enforcement against transnational criminal organizations in Mexico by the local authority. Criminal activity of the regional and Central American gangs involves not only drug trafficking but also alien smuggling, weapons smuggling and human trafficking.

\section{Art Theft}

Art and cultural property crime is an international problem involving theft and trafficking across national and international jurisdictions and borders. The black-market art trade includes stolen works of art and objects, looting of archaeological sites of antiquities, and illicit export and trade of international law protected artefacts. Combined estimated losses are in the billions of dollars. Significant efforts are currently directed towards ISIL (Islamic State of Iraq and Levant) pillaging and sales of cultural property to fund terrorist agenda. 


\section{Cargo Theft}

Cargo theft is a high priority concern due to the multi-dimensional negative effect ranging from the economic impact on the retail supply chain, disturbance on the flow of commerce and the possible threat to health and safety to consumers. Related crimes stemming from cargo theft are murder and kidnapping, robbery, money laundering, interstate auto theft, drug trafficking, health care and insurance fraud. Although health and safety issues are focused mainly on the theft of pharmaceuticals, food and beverage, and cosmetic or beauty aids. BSI reported an estimated $\$ 22.6$ billion worth of losses attributed to cargo theft in 2015.

\section{Jewellery and Gem Theft}

Jewellery and gem thefts account for an estimated $\$ 1.5$ billion loss to the jewellery and gem industry. These thefts are generally attributed to crime groups consisting of experienced thieves and can sometimes result in serious or mortal injury in the process. "Fences" are used to arrange the sales of the stolen items and launder the proceeds. The crime and transactions usually occur in different regional or geographic areas. The jewellery and gem industry and operational process are industry-specific requiring a specialized knowledge to conduct crimes that commonly involves a national or international scope.

Jewellery and Gem (JAG) related investigations include collaboration with the jewellery industry and local law enforcement, coordination of multi-divisional investigations, and provide support to field offices and international legal offices. The Jewelers' Security Alliance provides an industry-owned and maintained database available to the law enforcement.

\section{Organized Retail Theft}

Stolen food products, pharmaceuticals and other items that are not maintained under proper environmental conditions may be less effective or hazardous thereby threatening consumer health and safety, resulting in higher consumer prices and decreased sales tax revenue for the state and local governments.

The BKA centre of interest is on serious retail theft cases involving the interstate transportation of stolen property. Funds from retail theft crime provide the financial support for major crime rings to fund larger and more sophisticated organized criminal activities ranging from money laundering to terrorism, therefore it is identified as a "gateway" crime. The same techniques and strategies employed by the BKA to investigate organized retail theft is the standard used against most criminal organized crime. The BKA coordinate with law enforcement and officials from the local to Federal level to exchange information and collaborate on joint efforts. 


\section{Damage in Germany in Detail}

The damage caused by organized crime $(O C)$ rose dramatically in Germany last year - and has reached a value of more than one billion Euros. "In contrast to the previous years, in which there was a continuous decrease in the amount of damage, a clear increase was noted for 2016 (plus 137.1 percent)" says the Federal Organized Crime Situation Report.

The figures were published by the Federal Criminal Police Office (BKA) in Wiesbaden. With a total of more than 684 million Euros, the biggest damage goes back to economic crime, said a BKA spokeswoman.

Almost a third of this damage (296 million Euros) arose in a procedure with letterbox companies in so-called tax havens. It is being investigated for unauthorized financial services, investment fraud and money laundering.

After economic crime, tax and customs offenses (227 million Euros) caused the second highest damage, followed by property crime (54 million Euros). Cybercrime (29 million Euros) finished fourth. According to the report, the "classic focuses of organized crime" remain important: Italian organized crime (Mafia), Russian-Eurasian organized crime and rock-related crime.

The number of preliminary investigations decreased slightly (minus three cases) from the previous year to 563. More than a third of the suspected groups were drug dealers. Property crime proceedings increased by 14 to 98 . The two offenses accounted for more than half of all reported OC cases.

There was an increase from 53 to 61 in Berlin. In Bavaria, too, the number of proceedings rose from 70 to 76 , while it remained at 107 in North Rhine-Westphalia.

Of the 8,655 suspects (minus 20 suspects), just under a third had a German passport. In the opinion of the investigators, the perpetrators are becoming more and more professional. "This is reflected, among other things, in the high level of mobility" states the management report. Many groups travelled to Germany to commit crimes and then returned to their home countries. In addition, they increasingly used encrypted communications and the Internet to commit crimes.

The figures show that the perpetrators of organized crime "continue to be active in Germany", said Interior Minister Thomas de Maizière (CDU). "Organized crime destroys trust, undermines structures, and destabilizes state order."

\section{Review/Summary}

The following is a summary together with suggestions for improvement and assessment for future development. At the same time, tactics, national and international cooperation of various important bodies play a major role. 


\section{General}

It becomes clear that a criminal classification of the perpetrator side, as a single offender, gang or criminal organization has little importance in the criminal police's combating praxis.

The participants shield themselves as persons much less than was previously assumed. In conurbation $O C$ scenes, the perpetrators in local areas usually know each other personally, nationwide at least at the level of relevant persons. The police mostly know masterminds and helpers. Primarily, it is criminal police practice to keep nature and content of business relations secret, the preservation of business secrets. Current opportunities, interesting and lucrative offers as well as demands are kept secret from uninvolved and potential competitors. Business practices are being used that are also relevant in legal areas - e.g. in the brokerage or the import and export trade. With too much openness, businessmen would rob themselves of their business foundation. The risk of being ignored in current or subsequent business would increase significantly.

Personal foreclosure practices are by and large limited to those cases where personal communication is not a business necessity, and in which prophylactic avoidance of unnecessary personal risk should preclude unnecessary risks. This is mainly the case with the use of outsiders of the scene or by outsiders of the case, for example couriers of narcotics or transporters of stolen goods.

Foreclosure practices were and are mainly practiced by civil servants in central departments of territorial states. Allegedly well-sealed backers are generally well known, at least in the Federal Republic, to the local (offender-oriented) OC departments. The sudden appearance of leaders not known to the police is the exception.

However, this knowledge, which differs from the widespread view, does not refer to conspiracy in its entirety. Conspiratorial practices in all imaginable variations characterize the perpetrators' behaviour towards the police and business competitors in the field of business activities. In the leisure area on the other hand, they are usually completely open.

Market-economy considerations and security interests characterize the selection of offenses and victims. The perpetrators prefer crimes that promise very high profits in a short period of time and which reduce risks by the fact that there is no immediate casualty (drug trafficking, stolen goods), or where experience shows that the victim will not file a complaint (prohibited gambling, certain forms of white-collar crime, etc.). Consequently, in the OC range, a high dark field is assumed.

The use of "connections" is not always easy for foreign groups of perpetrators, especially not in the intended sale of illegal goods. Some groups are therefore either limited to areas where they are less dependent on sales channels (e.g. bank robberies and protection rackets), or they focus on areas of action that they can cover on their own from the first to the last stage.

Legal and illegal businesses are efficiently linked. The operation of a legal enterprise in addition to the illegal activity serves as camouflage, for the white washing of funds and for securing the existence. Illegally generated profits are mainly invested in 
real estate in Germany and abroad or invested in legally operated shops (trade, service industries). Investment in bank accounts or in securities and mobile assets (jewellery, antiques) is often practiced. The involvement of straw men is commonplace. The goal of this practice is not to minimize the risk. Primarily, it serves to obtain concessions of all kinds and to prevent access by the tax authorities.

Although the straw men practice of the perpetrator side is generally transparent to the police, they often cannot provide the corresponding proof to the courts and authorities. The many points of contact in economic life form the legal breeding ground for the OC.

\section{Assessment of Future Development}

Already, in the near future, a constant increase of the $O C$ relevant offenses can be expected. The share of $\mathrm{OC}$ in total crime will increase disproportionately compared to the overall development. But more important will be the qualitative changes. With the presumed increase in the number of dominating persons, special offender know-how will also be incorporated into the $\mathrm{OC}$ scene and increase the room for manoeuver. Furthermore, increased flexibility of the $\mathrm{OC}$ offender circles is to be expected.

A progressive integration of organized forms of economic crime with our economic and social system can be expected, without being able to speak of infiltration in the sense of mafia activities.

In such typical circumstances, an organized crime of its own kind emerges, the danger of which lies precisely in the fact that it is as diverse and flexible as the economy of our country, and it can profit from the freedom and opportunities in our society as it is wanted in the legal business world.

This dangerousness of the OC can hardly be estimated by the general public without corresponding information work of the police and the judiciary. The activities of OC are difficult to identify even by security experts in their magnitude and their negative consequences.

\section{Fight}

In the fight against organized crime, the police must, in addition to the actual investigation of criminal offenses, set the following main points:

The elucidation of the dark fields, in particular, the detection of the perpetrator connections, the prevention of the construction and the maintenance of offender contacts, and the "pulling out" of the initiators.

An intensification of the police fight against the $\mathrm{OC}$ can be achieved, in particular, by a combination of improvements in the areas of organization, tactics, training, law and public relations. 


\section{Organization}

According to the two basic forms of the $\mathrm{OC}$, the fight should also be organized in a doubletracked manner, side by side and co-existence of offender-oriented and case-related investigating OC departments.

Against the criminal offender entanglements in the metropolitan areas local OC offices should be determined by predominantly offender-oriented detection. Against independent groupings and those groups of perpetrators who set at least temporary delictary priorities, there must be predominantly case-oriented investigating $\mathrm{OC}$ departments at a central location. Both types of service are to be included in a comprehensive system.

The establishment of offender-oriented local OC offices in the territorial states and at the respective central offices seems problematic, in particular, because of the spatial distance to the target persons.

By creating special commissions, which should be kept small and composed of highly motivated officials, a powerful mix of the different types of service can be created on a case-by-case basis.

\section{National Cooperation}

The fight against the OC can only be successful in the long term if it is linked to all OC services. The national criminal offender connections must face personal official contacts in the police area. Such an informal communication network could help in the short term to significantly increase the flexibility of the police.

The formal mutual flow of information between the OC processing departments also requires intensification. In addition, the essentially unilateral flow of information from the entire police base to the OC services should be improved. This can be achieved, in particular, by means of appropriate education and training measures (sensitization).

\section{International Cooperation}

International cooperation - particularly in urgent cases - should be improved through the strengthening of mutual support within the ICPO-Interpol as well as through bilateral and multilateral agreements. Even in relation to foreign police authorities, the informal investigator contacts must be intensified.

\section{Cooperation of the Police with the Prosecution and Administrative Authorities}

Co-operation with the public prosecutors' offices can be significantly improved by the nationwide establishment of OC prosecutorial offices. On the one hand, they could expand their expertise by participating in local police operations and by participating in 
police training and, on the other hand, sensitize police officers to criminal procedural peculiarities.

The involvement of administrative authorities (immigration office, trade office, tax office, etc.) is of great importance, especially with regard to the overlapping of criminal and legal activities. The high flexibility of the OC scene also demands rapid action on the police side. Just reacting with bureaucratic delays, does not break the OC decisively. Retracted tracks must be largely abandoned.

Owing to the high degree of threat posed by the impact of the $O C$ scene, the OC services are to be physically sealed off from the rest of the police apparatus. This must be done in a way that does not hinder the unilateral flow of information from the police base to the $\mathrm{OC}$ office.

\section{Evaluation of the Success of the Investigation Work}

Organized crime is difficult to capture or grasp statistically. This also applies to the police statistics used to date for the allocation of staff and budgetary resources. The lengthy and extensive investigations required in OC cases can hardly be evaluated in numbers. Their success often lies only in the preventive disturbing of the scene. It is therefore necessary to arrive at a qualitative assessment of the $\mathrm{OC}$ investigation work.

\section{Tactics}

Suspicions and evidence must not only be collected at OC but worked out. In particular, the procurement of evidence requires active action.

Undercover investigations are indispensable in order to counter the conspiracy of the OC offenders. It requires the targeted use of covert agents and the support of $\mathrm{V}$-persons.

A better financial and practical equipment of the undercover investigators and increased funds for the remuneration of $\mathrm{V}$-persons are required.

Persecution pressure, including unconventional police action, can create uncertainty in the OC scene. Considered, for example, are the presence at milieutreffs, incalculable controls, observations, telephone monitoring, but also the mere announcement and the control of false information/rumours) of a different kind. Such actions prevent the $\mathrm{OC}$ scene from further consolidating. It causes the perpetrators to resort to evasive actions that give rise to starting points for the investigation work.

In the first place, the fight should be directed against outstanding leaders who are well known to the police. A determination of the relevant target persons seems important.

Since the cohesion in the OC scene largely depends on the common benefit and profit, the detection and seizure of crime profits, especially in this crime area, are extremely important control tools. 
The training and further education of $\mathrm{OC}$ officers must meet the special requirements of the OC. It should cover in particular the following areas: jurisprudence, practice of covert investigations, OC typical offender behaviour and know-how.

In addition, every police officer should be aware of the main manifestations of the $O C$ and of these indicative indicators through education and training events. In addition, he has to be taught sustainably the importance and danger of the OC. 